\title{
農村住居における生活単位と住まい方を通してみた 通世代家族の住空間
}

\author{
A BASIC STUDY ON THE LIFESPACE OF THE EXTENDED FAMILY \\ AT RURAL HOUSE TO RESEARCH THE RELATION BETWEEN \\ THE UNIT OF FAMILY AND THEIR LIFESTYLE
}

\author{
岡 部 雅 美*2, 伊藤 庸一*1 \\ Masami OKABE and Yoichi ITO
}

\begin{abstract}
In our time, there are various family which are single-person-households, nuclear family and,extended family, etc. In this paper we will clear up the lifespace of the extended family.at rural house by researching the relation between the unit of family and lifestyle of 17 th extended family. We cleard as follows:

1) The extended family inherit customary lifestyle which are eating, cooking, conversing and holding ceremony together with family. As another, the husband and wife or children of the extended family eat, cook, hold conversation and receiv by oneself.

2) The extended family inherit the mutual aiding that is customary lifestyle. Each member of family has one's part and helps to each other.

3) The extended family put much value on the living with extended family.

4) We conclude that the living with, extended family will be inherited.
\end{abstract}

Keywords:rural house, extended family, function of family, living with extended family, unit of family, lifestyle, mutual aiding

農村住居、通世代家族、家族の機能、同居、生活単位、住まい方、相互扶助、

1.はじめに 農村の住居ではかつてより通世代家族"1 が一般であり、その住まい方には地域ごとの特徵がみら

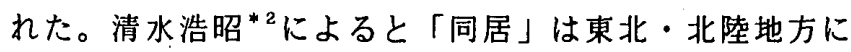
多く、「别居（隠居）」は四国・九州地方に多いと言わ れている。いずれの通世代家族にも共通することは、先 祖代々その地域で世代の異なった人々が共に暮らし、安 心した生活を営んでいたと言うことである。

農村の家族は、通世代家族を構成する成員が役割を分 担することで生業を充実させ、生産・生活を支えてきた。 また、通世代家族では高齢者自身も家族の一員としての 位置づけが確保され、高齢者のこれまでの経験が大切な 知識として尊重されていたので、家族から除外されるこ とはなかった。川本彰の「近代社会における家の構造」 *3を引用すれば、家族の機能は(1)文化の伝承、(2)人格の 形成、(3)子供の育成、(4)経済的な安定であり、農村の家
族はこれらの家族の機能を充足していた。「イエ制度」 などのしがらみもあったが、農村の通世代家族はかつて の日本の家族像として定着していた。

戦後、「イエ制度」が廃止され「個」の尊重が顕著と なった。また、農業社会から工業社会へ移行し雇用化が 進展するなとの産業構造が変化した。その結果、家族の 生活の場と職場の分離が著しく、農村では新しい職業を 求めた若い世代の流出が著しくなった。農業を生業とし ていた家族では家族人数が多いことは働き手が多いこと を意味していたので通世代家族が適当であった。しかし、 雇用化の波及にともない動く場所に身軽に移動できる小 家族が適当となり ${ }^{* 4}$ 、結果として、高度成長期には夫婦 とその子からなる核家族が日本の家族として定着した。 近年、ますます「個」が尊重され、家族形態も多岐に わたり一概に日本の家族像を言い表すことは難しくなう

*1 日本工業大学建築学科 教授・工博

*2 日本_工業大学建築学科 特別研究員 - 【一修
Prof., Dept. of Architecture, Nippon Institute of Technology, Dr. Eng. Postgraduate, Dept. of Architecture, Nippon Institute of Technology, M. Eng. 
てきている。多様な家族形態がみられる現在の家族観は、 夫婦別姓なとが主張されるように、個人の「人格」を尊 重したものになった。つまり、家族像は「生業と生活を 共に営んできた生活共同体」（極相）から、近代化の中 で「個」の主張や㕍用化の進展により家族像が変化し （遷移）、高度成長をむかえた時期では核家族が定着 （極相）、さらに高度成長が低迷し「個」が誇張され人 格を尊重した多様な家族像が表出（遷移）、という極相 $\rightarrow$ 遷移 $\rightarrow$ 極相という経緯を踏まえ、現在、再び遷移の時 代を迎えている（図 1）。

一方、こうした家族像の变化とは別に高齢化や住宅難 なとの社会問題が否応なしに進むなか、通世代家族の相 互扶助や介護機能に対する憧憬が強くなってきている゙5。 また、住宅供給においても二世帯住宅が著しい。 ${ }^{* 6}$ 住宅 金融公庫による「二世帯住宅割增融資の動き」をみても ここ $7 \cdot 8$ 年の間、急激に二世帯住宅の供給がのびてい ることがわかる*7。供給されている二世帯住宅は従来の 通世代家族の住まい方をそのまま踏媻しているのではな く、建築計画学研究等ですでに明きらかとされているよ うな*8、嫁と姑の問題、世代間の生活時間や生活の仕方 のずれなどの問題を考慮した新しい生活スタイルを提示 している。しかし、世帯別に生活領域を分離するスタイ ルが多く、世代の異なる家族成員が共に暮らす意味がう すれているようにも感じられる。

つまり、現在、個人の人格を尊重する価値䲅をもつ人 々による多様な家族形態が表出する一方で、高龄者を含 めた三・四世代家族が住める住居が嗜好されており、新 しい家族観を背景とする新しい三・四世代家族の住まい 方とその住空間 ${ }^{* 9}$ が模索されているといえよう。

こうした家族観が変化するなか、これまで行われてき た研究をみると、三世代同居に関する研究では都市およ び都市近郊を対象とし、三世代家族を親世帯と子供世帯 に分け、2つの世帯がどのように住み合っているかとい う論文が多い。一方、農村を対象とする研究は少なく、 隠居慣行の住まい方や㩊居を慣行とする地域での住まい 方変化に関する研究がみられるだけで、家族観の変化を 背景とする、農村の同居を慣習とする地域を対象とした、 新しい通世代家族の住空間に関する研究はみられない。

本研究では従来より三・四世代家族（通世代家族）が 共に暮らし、家族観の変化に大きく影響されながらも、 今なお通世代家族が住み続けている農村を対象とし、農 村での通世代家族の住まい方と住空間の特徵を捉え、新 しい家族観が波及する現代における通世代家族が共に住 む可能性と、現代社会にみ合った通世代家族の住まい方 とその住空間形成の指針を得ることを目的とする。

2. 家族の定家族社会学では家族を「夫婦とその子 からなる第 1 次福祉集団」*10 と定義し、その家族形態 として直系家族・複合家族などをあげている。しかし、
森岡清美の「新しい家族社会学」 ${ }^{* 10}$ の中でも指摘され ているように、現代社会での家族は多棣であり、家族の 意味も変化している。現在では多様な家族形態がみられ るが、本稿では、前述したように「家族の機能」を充足 し、家族成員それぞれが家族の一員として位置づけられ てきた通世代家族を取り上げる。

近代化により農村の家族から若者が流出した。また、 現在でも単身赴任や進学のための転出など一時的に家族 と離れ生活をしている人もいる。本稿ではあくまでも家 族の機能を充足できる家族成員の集団を家族と位置づけ ており、経済的につながっている一時的な転出者も家族 の成員とみなず1。

農村の家族の特改は、土地があるためか永続的にその 土地で家族が生活を営む傾向が高いということであろう。 森岡清美 ${ }^{* 10}$ が提示する家族の成長段階を参考に農村の 家族の成長をみると、次男や三男は結婚を機に本家から 分家し自分の家族の核をつくる（第 1 段階）。やがて子 供が生まれ（夫婦と幼児の家族＝第 2 段階）、その子供 が小学校へ進学し自立し始める（夫婦と自立した子供か らなる家族＝第 3 段階）。その自立した子供が結婚をし 二世帯家族となり（夫婦と若夫婦からなる家族＝第 4 段 階）、子供夫婦の子供が生まれた段階で三世代家族（夫 婦と若夫婦と子供からなる家族＝第 5 段階）となる。そ して三世代家族は年長者世代の他界や次世代の誕生を繰

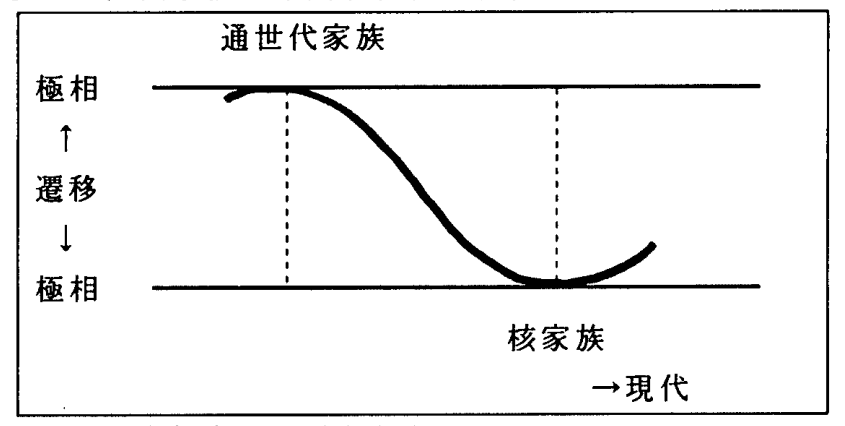

図 1 家族像の要移と極相モデル

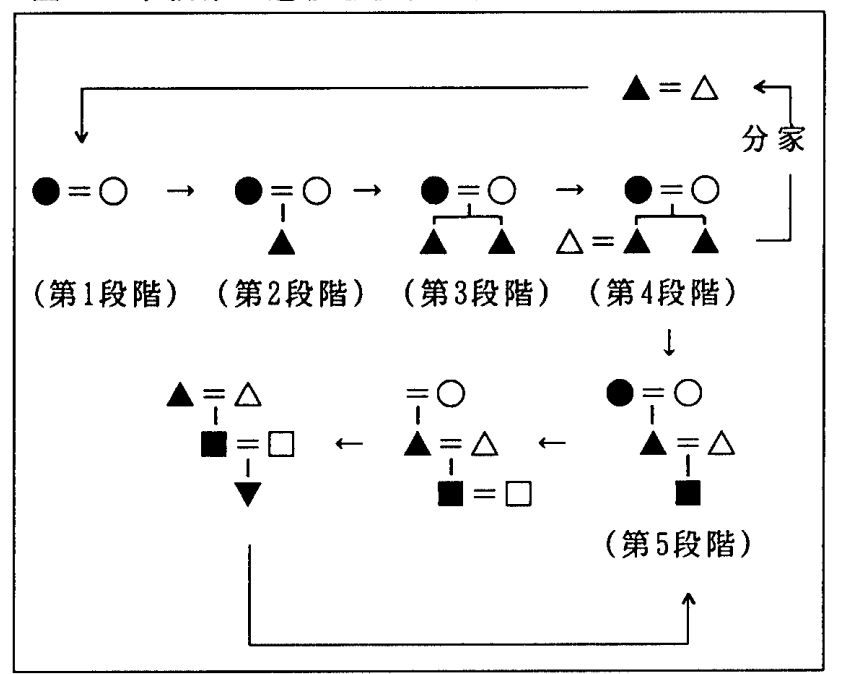

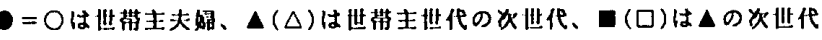
図 2 農村家族の成長段階モデル 
表 1 対象事例の概況

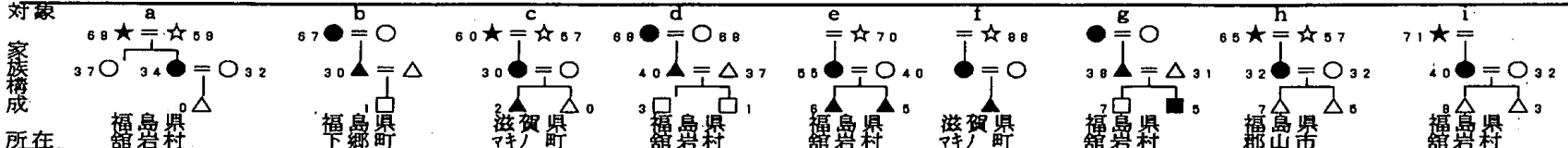

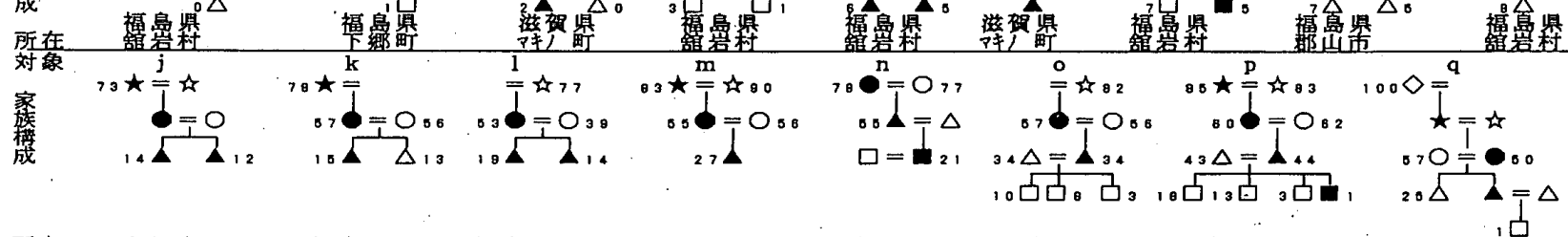

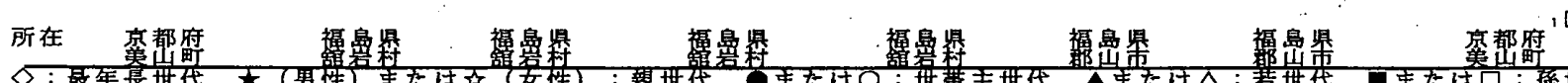

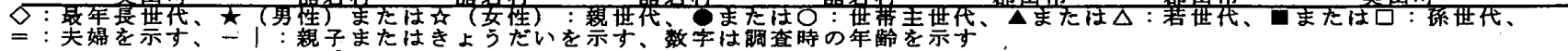
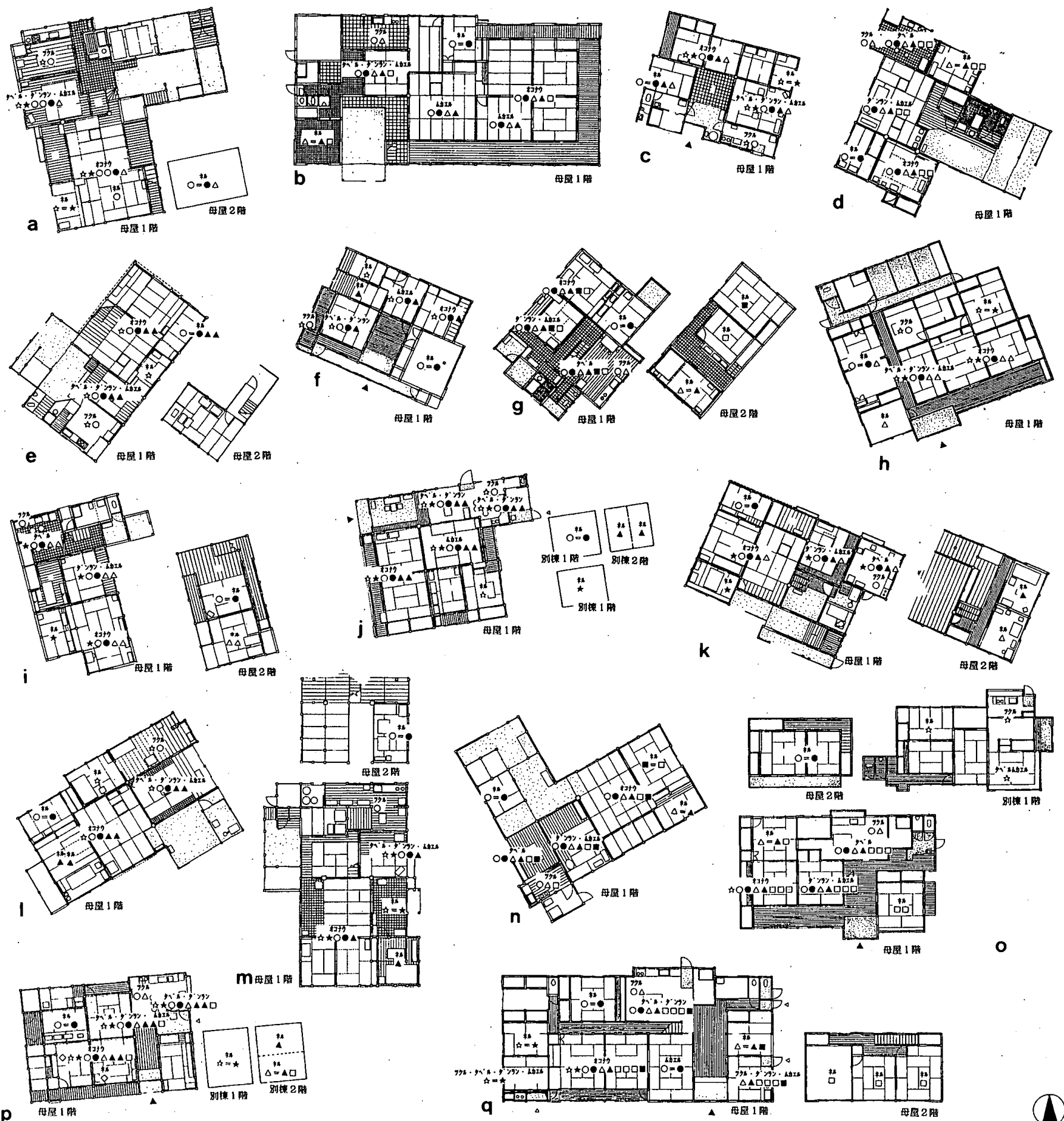

図 3 間取りと住まい方 
り返しながら通世代家族として永続的に存続する。一方 第 4 段階の時に分家した次男や三男は第 1 段階に戻り、 新しい通世代家族にむかって成長する。つまり、農村の 家族は分家から通世代家族にいたるまで遷移し、通世代 家族となったとき極相状態を迎える。そして、極相状態 を保ちながら、次世代へと永続的に家族を持続する（図 2) 。

3. 調查地の選定方法と調查概要 1) 調查対象の選定 調査対象は次の順で選定した。(1)日本での同居を慣習 とする地域を抽出するため、前述した清水の「東北・北 陸に同居が、四国・九州に別居（隐居）が多い」*2とい

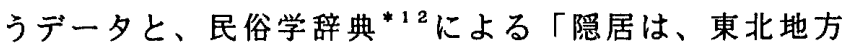
や日本海側にはみられず、濃厚な伝承がみられる地域は、 磐城・常盤を北限として伊豆諸島、三河の一部、志摩か ら熊野にわたる諸地域、瀬戸内海の島、四国、九州」と するデータを日本地図に示し、おおまかに同居を慣行と する地域を抽出。(2)同居を慣習とする地域のうち、一般 世帯における家族数が $5 \sim 6$ 人以上である地域 ${ }^{* 13}$ 、中 大路美智子の「高齢単身世帯の住宅事情に関する考察」 *11より捉えられた「高齢者率が比較的高く、単身世帯 率が低い地域」、小川正光の「老人を含む世帯の住宅事 情における地方類型」"15 の中で「伝統的な大家族の住 生活を表す因子と、老人人口が多く、戦前からの定住も 高い因子、農村的な住み良さを示す因子の3つの因子が 示す地域」のデータを参考にし、対象とする都道府県を 選定。(3)選定した都道府県の中で、比較的地域の特徵的 な平面構成をもつ住居が多く現存する農村地域 ${ }^{* 16}$ (福 島県舘岩村 - 福島県郡山市・福島県下郷町 - 滋賀県マキ ノ町・京都府美山町）を取り上げ、(4)それぞれの地域の 中で、今なお通世代家族が同居を営んでいる 17 事例を 対象として選定した。2)調査の方法 対象事例では、 (1)間取り採図調查、および、(2)主として世帯主夫婦を回 答者とした、家族構成・住まい方・家族成員間の相互扶 助・通世代家族の利点欠点・住まい方のコツなどに関す るヒアリング調查を実施した。

4. 現代的な通世代家族の住まい方特性 1) 対象事例 の概要 対象事例の家族数は 4 〜 10 人と分布するが、 6 人家族が最も多く、平均すると 5.95 人である。家族の世 代構成は、親世代（世帯主を交替した世代）十世帯主世 代十若世代（世帯主世代の子供のうち未婚者）、あるい

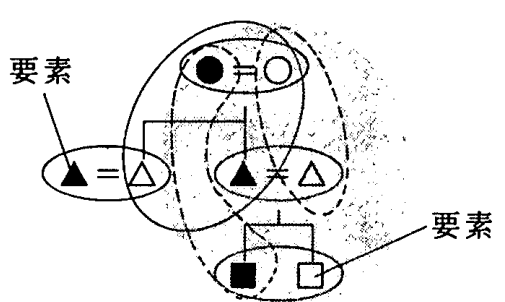

通世代家族—要素的関保 複合的関係

図 4 通世代家族の家族関係
は世帯主世代十若夫婦世代（世帯主世代の子供のうち既 婚者）十孫世代（若夫婦世代の子供のうち未婚者）とい う三世代家族が14事例、親世代十世帯主世代十若夫婦世 代十孫世代という四世代家族が 2 事例、最年長世代（親 世代の親）十親世代十世帯主世代十若夫婦世代十孫世代 という五世代家族が 1 事例である。

母屋は比較的各地域の特徵を表す平面で構成され、家 族数に応じて母屋の他に別棟がもうけられている。母屋 は比較的平屋建てが多いが、住要求に応じた改築や增築 により、調査時点では平屋建て母屋（7事例）のほかに、 2 階建て母屋（7事例）や平屋建て母屋と别棟（2事例）、 2 階建て母屋と別棟（1事例）がみられる。また、部屋 数は地域性や別棟の有無、住居の大きさによって異なる が、7〜9部屋構成の住居が多い（表 1，図 3）。

2) 通世代家族の生活単位家族社会学では、家族とは 夫婦と子供からなる第 1 次福祉集団とされている。これ を踏まえると、通世代家族とは核家族が連続した集団と いえる。家族を構成する成員（個人）を要素とすると、 夫婦は要素が婚姻というかたちで組合わさった集合体で あり、子供と親は血縁という枠組みでくくられる。一般 に家族社会学では夫婦や親子、きょうだいなどの関係を 要素的関係といい、嫁と姑、祖父母と孫など、要素的関 係のある要素を介し、核家族の枠をこえた関係を複合的 関係と定義している*10（図4）。

そこで、まず、家族社会学で定義されている家族関係 を参考に生活単位（生活行為を行う要素の組み合わせ） を抽出する。

通世代家族は世帯主、世帯主婦（世帯主の妻）・親夫 （世帯主の父親）・親婦（世帯主の母親）・若夫（世帯 主夫婦の結婚した子供またはその夫）・若婦（世帯主夫 婦の結婚した子供またはその妻）・若世代（世帯主夫婦 の末婚の子供）・孫夫（世帯主夫婦の結婚した孫または その夫）・孫婦（世帯主夫婦の結婚した孫またはその妻） - 孫世代（世帯主夫婦の未婚の孫）・最年長夫（世帯主 の祖父）・最年長婦（世帯主の祖母）という要素で構成 される。これらの要素が、生活行為を行うとき、どのよ うな組み合わせをみせるかというと、世帯主夫婦・若夫 婦・親夫婦・孫夫婦・最年長夫婦など、婚姻によって組 合わさった夫婦単位、兄弟・姉妹のきょうだい単位、嫁 と姑の単位（嫁姑単位）、夫婦と子供の核家族単位、三 世代家族のうち孫世代をのぞいた世帯主世代十若夫婦世 という単位（2/3 単位）、四世代家族のうち親世代を のぞいた世帯主世代十若夫婦世代＋孫世代という単位 ( $3 / 4$ 単位)、五世代家族のうち最年長世代をのぞい た世帯主世代十若夫婦世代十孫世代という単位（4/5 単位）、すべての要素が組み合わさった通世代家族単位 の 7 つの家族関係がみられる。さらに、この7つの家族 関係に加えて、要素が単独で生活行為を行う場合を考慮 
すると、通世代家族の生活単位は、上記 7 つ家族関係 と単独で生活行為を行う要素の8つとなる。

3) 通世代家族の生活単位と生活行為との関係（図 5)

本稿では、詳細な生活行為では通世代家族の住まい方 の特徵が捉えにくいと考え、住居学での生活行為分類を 参考に、「ネル (就寝)」「ックル（炊事）」「タベル (食事)」「タンラン（団らん）」「ムカエル（接客）」 「オコナウ（行事・儀式）」の6つの行為を生活行為と して取り上げる*17。

生活単位と上記 6 つの行為を対応させると、「ネル」 では要素単位・夫婦単位・きょうだい単位・核家族単位 がみられ、生活単位は、最年少世代の成長段階や世帯交 替に関係する。すなわち、若夫婦とその子供の「ネル」 における生活単位は、子供の成長にあわせ順次、核家族 単位から、夫婦単位ときょうだい単位あるいは夫婦単位 と要素単位へ分離し、さらに、きょうだい単位は要素単 位へ細分化される。また、世帯を交替した親夫婦は、夫 婦単位から要素単位へ「ネル」の生活単位を変化させる 傾向をみせる（図6）。「ックル」では、主として嫁姑 単位あるいは要素単位がみられるが、加えて、夫婦単位 あるいは核家族単位がみうけられ、生活単位に重層性を みせる。すなわち、嫁姑単位あるいは要素単位での「ツ クル」は通世代家族単位の「タベル」に対応し、その 「ックル」に平行するかたちで、夫婦単位での「タベル」 や核家族単位での「タベル」に応じた「ックル」が存在 する。「タベル」は「ックル」と連動するかたちで生活 単位が定まり、結果として「ツクル」の生活単位の重層

\begin{tabular}{|c|c|c|c|c|c|c|c|}
\hline 生活単立 & 㰯骂 & 齐 & ツクル & タベル & $y^{*} \cdot 9^{\prime}$ & L力II & \begin{tabular}{|l|l|} 
\\
\end{tabular} \\
\hline \multirow{6}{*}{ 要素単位。 } & &. & & & & & \\
\hline & $\frac{\hbar}{4}$ & $\ldots$ & 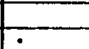 & $\because$ & & & \\
\hline & 8 & & & & & & \\
\hline & $\Lambda$ & $\ldots$. & & & & & \\
\hline & & .. & & & & & \\
\hline & $\frac{2}{1}$ & 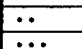 & & m & & - & \\
\hline \multirow{3}{*}{ 夫婦単位 } & 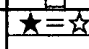 & $\ldots \ldots$ & 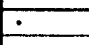 &. & . & . & \\
\hline & $\theta=0$ & ........ & & & & & \\
\hline & $\Delta=\Delta$ &. & & & & & \\
\hline \multicolumn{8}{|l|}{ 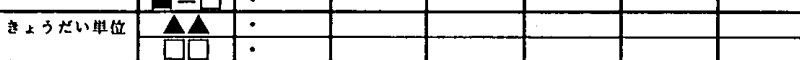 } \\
\hline \multirow{3}{*}{ 核家族単位 } & $\frac{11}{Q=0}$ & $\ldots$ & & & & & \\
\hline & $\Delta \Lambda$ & 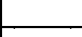 & & & & & \\
\hline & 贶 & & 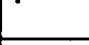 & & 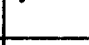 & $10^{\circ}$ & \\
\hline \multirow[t]{2}{*}{ 嫁姑単位 } & 270 & & $\because \cdots$ & & & & \\
\hline & 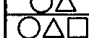 & & $\cdots$ & & & & \\
\hline \multirow{2}{*}{ 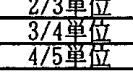 } & & & & 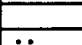 & 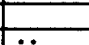 & $+\circ$ & \\
\hline & & & & & & & \\
\hline \multirow[t]{2}{*}{ 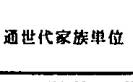 } & & & & $\ldots \ldots .$. & $\ldots \ldots$. & $\ldots \ldots$ & $\cdots \cdots$ \\
\hline & & & & & ... & & 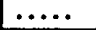 \\
\hline
\end{tabular}

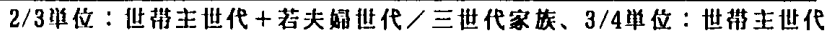

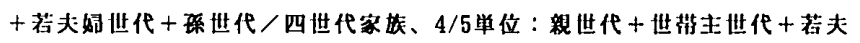
婄世代十啋世代/五世代家模示す。 $\cdot=1$ 生活単位

図 5 生活単位と住まい方との関係

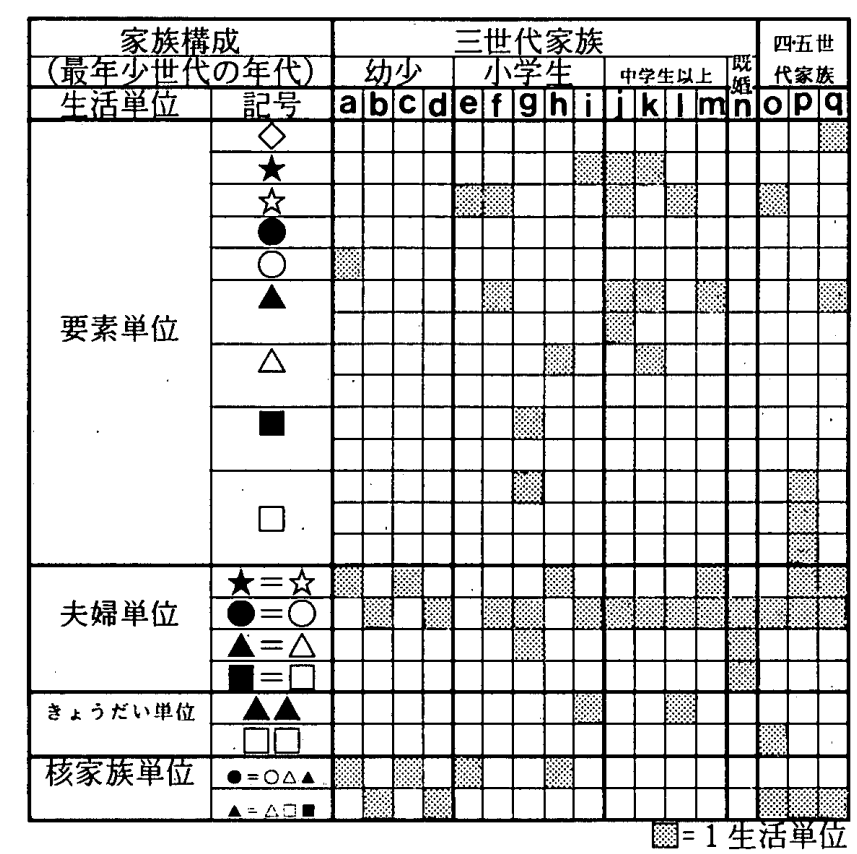

a 〜 の郡号は各事们を示す

図 6 「ネル」での生活単位.

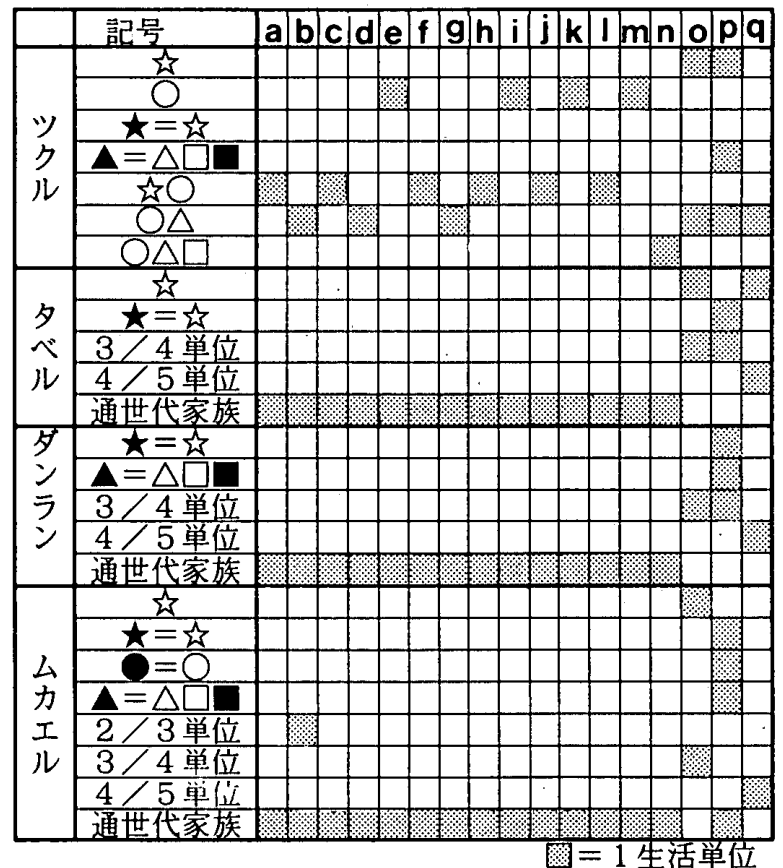

図 7 生活行為別にみる生活単位の重層生

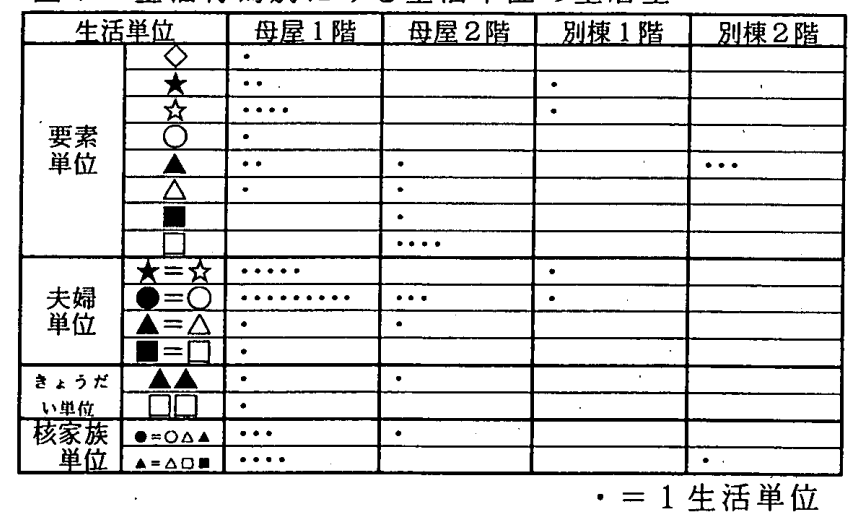

図8 生活単位別にみる「ネル」での部屋利用 
性に連動し、「タベル」の生活単位にむ重層性が表れる。 「ダンラン」は通世代家族単位が多くみられるが、重層 するかたちで、夫婦単位あるいは核家族単位がみられる ほか、親世代をのぞいた $3 / 4$ 単位や $4 / 5$ 単位の生活 単位もみうけられ、「ダンラン」の生活単位の複雑化が 示唆される。また、「ムカエル」では、通世代家族単位 がほとんどをしめるが、夫婦単位あるいは核家族単位で の「ムカエル」もみられる。「ムカエル」での生活単位 の重層性は、客層の違いによって生じる。最年少世代の 「ムカエル」は比較的、幼少の頃から要素単位がみられ る（図 7）。一方、「オコナウ」では通世代家族単位が 主で、他の生活単位の重層性はみられない。

具体的にみる。(1) a のように三世代家族で最年少世代 が幼少（小学校入学前段階）の場合：「ネル」では夫婦 単位と若夫婦と孫世代の核家族単位がみられ、「ックル」 では嫁姑単位、「タベル」「ダンラン」「ムカエル」 「オコナウ」では通世代家族単位がみられる。(2)hのよ うに三世代家族で最年少世代が小学生の場合：「ネル」 では夫婦単位と核家族単位（世帯主夫婦と幼少の若世代）、 要素単位（小学 2 年の若世代）がみられる。「ックル」 は嫁姑単位で、「タベル」「ダラン」「ムカエル」 「オコナウ」は通世代家族単位で営まれる。また、iの ように「ネル」にきょうだい単位がみられる場合もある。 (3) mのように最年少世代が既婚の場合：「ネル」では夫 婦単位のみがみられる（若世代は結婚を機に要素単位か ら夫婦単位となる）。「ツクル」は三つの世代の嫁姑単 位、「タべル」「タンラン」「ムカエル」「オコナウ」 は通世代家族単位で営まれる。(4)。のように最年少世代 夫婦の子供が誕生するなど、四・五世代家族の場合： 「ネル」では要素単位・夫婦単位・核家族単位・きょう だい単位とさまさまな生活単位が表れる。「ックル」に は嫁姑単位に加えて要素単位がみられ、「タベル」では $3 / 4$ 単位と要素単位が、「ダンラン」は $3 / 4$ 単位、「ム カエル」は3/4単位のほか要素単位が表出するなど、生 活単位の重層性がみられる。しかし、「オコナウ」は通 世代家族単位で営まれ、生活単位の重層性はみられない。 4)生活行為別に見る部屋の利用 前述のように、現代 の通世代家族の住まい方の特徵は、「ネル」にみられる 家族の成長段階に応じた生活単位の変化と、「ックル」

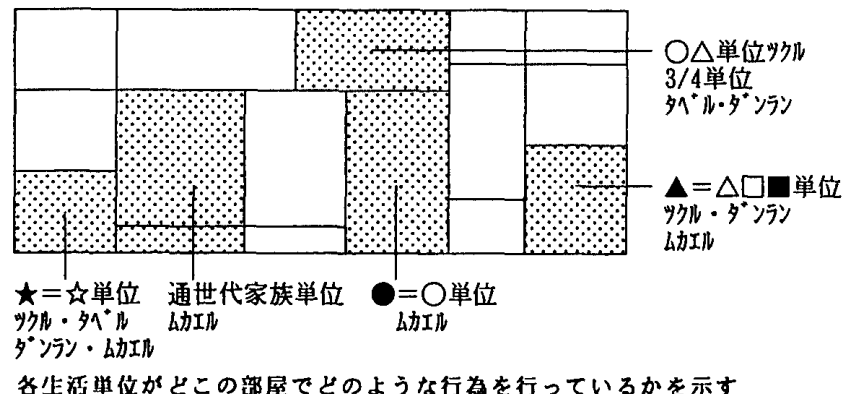

図9重層する生活行為での部屋の利用例 (事例: $p$ )
「タベル」「ダンラン」「ムカエル」にみられる生活単 位の重層性である。こうした特徵的な住まい方での部屋 利用を検討すると、「ネル」での部屋利用は、生活単位 别よりも年代によって利用される部屋が規定される（図 8 ）。すなわち、夫婦単位のうち世帯主夫婦の「ネル」 部屋を母屋 1 階に位置づけ、若夫婦や孫夫婦は 2 階の部 屋を「ネル」部屋として利用する。また、要素単位では 親世代の「ネル」部屋を母屋 1 階にもうけ、若い世代ほ ど母屋 2 階や別棟に「ネル」部屋を確保するほか、一時 的に「オコナウ」部屋を兼用する。要素単位の若世代が 既婚し、夫婦単位になると、要素単位で利用していた 「ネル」部屋として利用する。

生活単位の重層性がみられる生活行為（「ックル」 「タベル」「ダラン」「ムカエル」) では、通世代家 族単位（嫁姑単位）で利用する「主（メイン）」の部屋 と、重尿する生活単位が利用する「副（サブ）」の空間 がもうけられ、生活単位の重層性は空間構成に連動する

（四12）。すなわち、「ックル」をみると、嫁姑単位は 母屋 1 階の部屋を利用し、重層する要素単位あるいは夫 婦単位の部屋は、別棟 1 階あるいは母屋 1 階の別の部屋 を利用する。「タベル」部屋・「タンラン」する部屋・ 「ムカエル」部屋においても、通世代家族単位は母屋 1 階の部屋がを利用し、重層する要素単位あるいは夫婦単 位、核家族単位の部屋は、母屋 1 階の別の部屋を利用す る(図 9 )。

「オコナウ」では母屋 1 階の部屋を利用し、別棟や母 屋 2 階の部屋の利用はない。

5. 要間の役割分担と相互扶助「1。はじめに」で 記したように、近年、通世代家族の相互扶助や介護機能 への憧憬が著しい。しかし、一方ではあまり干涉された くないと言うプライバシィの尊重も顕著である。

かつての通世代家族では、家族が一体となって生業 （農業）を共に営んでいた。しかし、現在では、農業を 世帯主夫婦あるいは親世代が営み、他の世代は比較的、 外に動きに出ている。特に、世帯主婦あるいは若婦が外 へ働きに出る傾向は以前と比べ著しい。

通世代家族が家族の機能を充足するためには、要素間 の相互扶助が必要不可欠である。まして、世帯主婦ある いは若婦が外へ働きに出る傾向が著しくなった今日，ま すます要素間の相互扶助が必然となる。世带主婦あるい は若婦の外の職の有無に影響される家事では、世帯主婦 ・若婦の相互扶助が著しい。すなわち、嫁姑単位で行う 「ックル」では世帯主婦が主として行い、その親婦ある いは若婦が手伝うかたちで行う。しかし、世帯主婦ある いは若婦が外で働いている場合、朝・昼・夜と「ックル」 作業を分担し、お互いに手伝いあう。また、親世代夫婦 単位が「ックル」で重層している場合は、嫁姑単位によ るおかずの差し入れなどがみられる。掃除のうち、「ネ 
ル」部屋についてはそれぞれの生活単位が掃除を行うが、 家族が共通に利用する部屋については、主として世帯主 婦あるいは若婦が行い、若婦や親婦が手伝う。掃除でも 世帯主婦あるいは若婦の外へ働きにでる状況に応じた、 週末にいっしょに行う・部屋を分担する・屋敷内と庭で 分担するなどのエ夫が施されている（図 10）。ただし、 重層する生活単位で利用する部屋は、それぞれの生活単 位の要素が掃除を行い、他の生活単位は立ち入らない。 洗濯では、家族全員分を世帯主婦が中心に行う傾向をみ せるが、一部では、共同の洗濯機を利用するものの、夫 婦単位あるいは核家族単位で洗濯を行う場合がみられる

（図11）。

子供のしつけでは、主としてその子供の両親が行う傾 向みせるが、家の慣習やしきたりなどについては、祖父 母にあたる世代が行う。また、両親が外へ働きに出てい る場合は、祖父母にあたる世代が日中も子供の世話を行 い、両親世代を助ける（図 12）。

先祖代々行われてきた毎日のお供えは、神棚・仏增を 問わず、女性や若い世代が行うことは少なく、主として 世帯主あるいは親夫が行う（図13）。

通世代家族の特徵でもある介護機能については、家族
のうち夫が病気になるとその妻が看病をし、妻が看病に 時間を要して行えなくなった家事を他の世代が行い、妻 を助ける。妻が病気になると、看病は親世代や次世代の 妻が行い、看病に手が取られる分、行えなくなうた家事 は、男女を問わず要素が互いに助け合う（図14）。

通世代家族単位で行う「オコナウ」では、式の準備は 男性、式のための「ックル」は女性が担う。式の準備で は、世帯主が中心となり、親世代がアドバイス、次世代 が手伝うという仕組みがとられる。一方、「ックル」は、 世帯主婦が中心となり、親世代はアドバイス、次世代が 手伝うという仕組みで行われる（図15）。

6. 通世代家族の同居への志向これまで捉えてきたよ うに、現代の通世代家族は、かつての通世代家族にみら れたような要素間の相互扶助や介護機能を温存させ、生 活単位あるいは生活行為に応じた部屋を重層にすること で、新しい現代的な同居の住まい方を営んでいる。

同居に対しても「相互扶助」「祖父母と孫の交流」 「楽しい」「安心」などの多くの利点をあげ、久点がみ られないくらいに同居の住まい方を高く評価している。

また、現在の「ックル」「タベル」「ダンラン」「ム カエル」、それぞれの生活行為に応じた部屋の重層化に

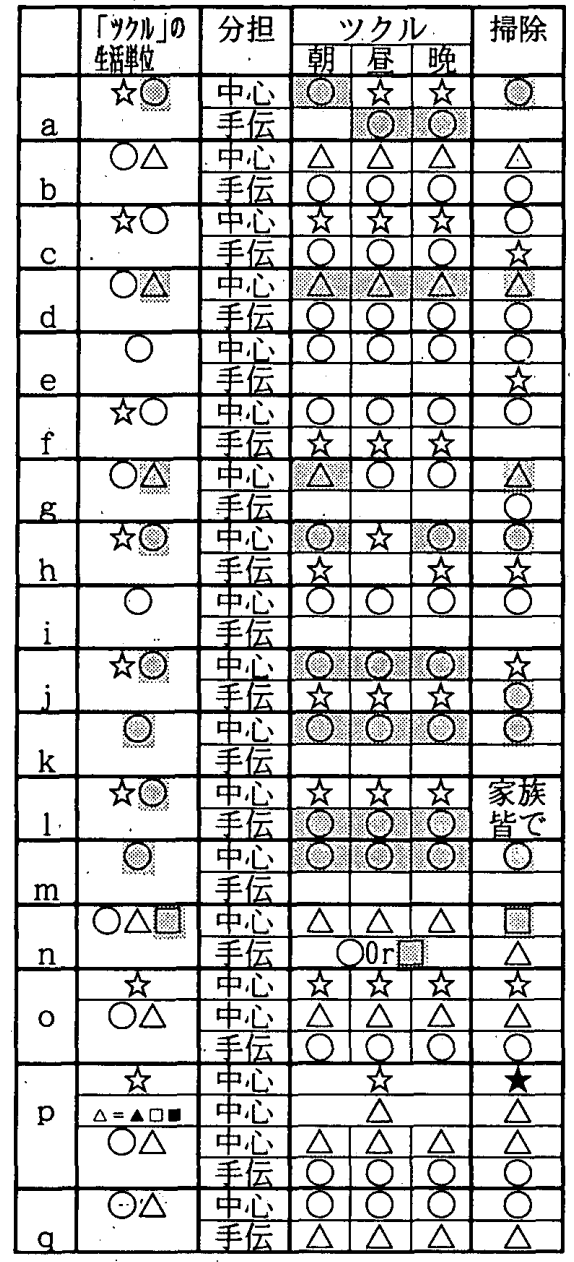

図 10 家事での相互扶助

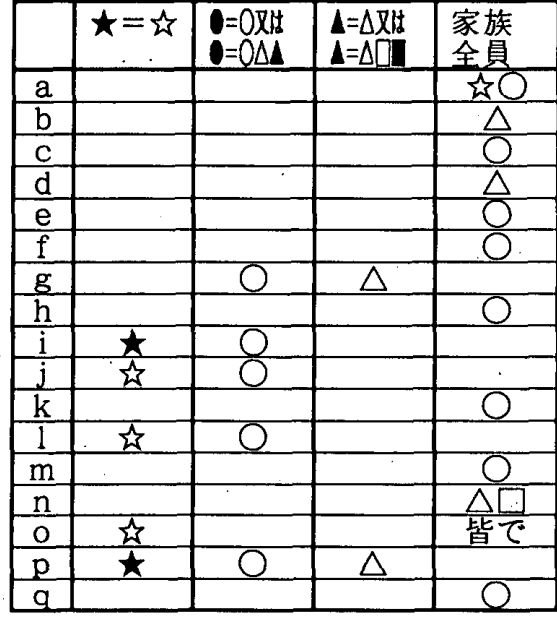

図11 洗濯での相互扶助

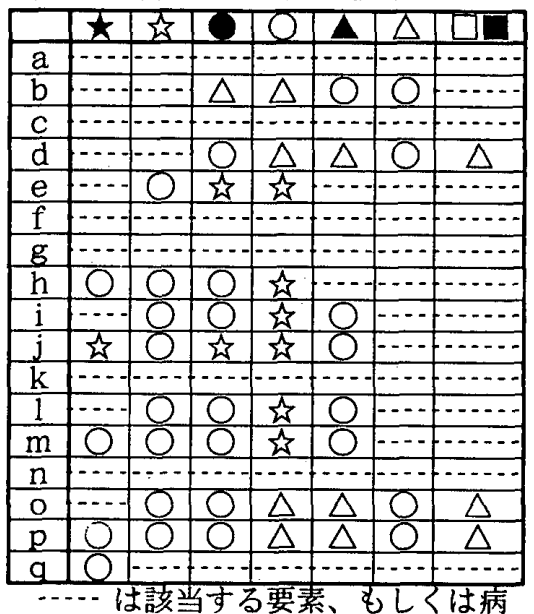

気になった要素がいない場合を記す

図14 介護での相互扶助

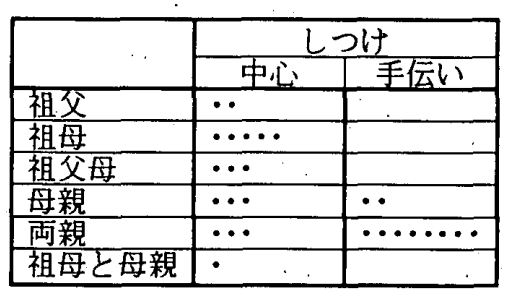

$=1 \pi$

図12 いかでの相互扶助

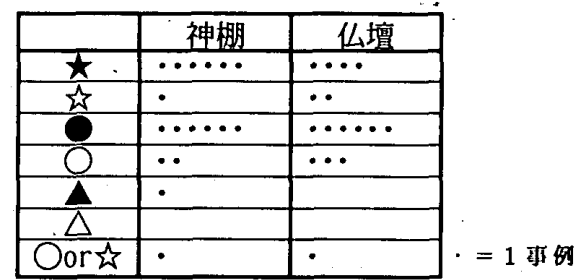

図 13 占斯での役割分担

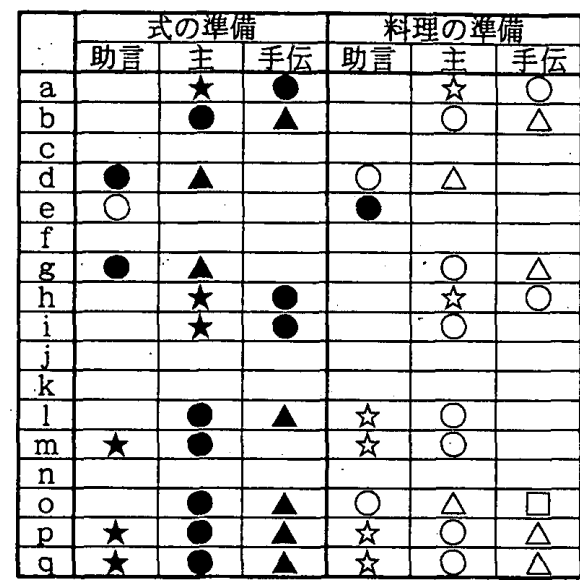

困15「才コナウ」での相互扶助 


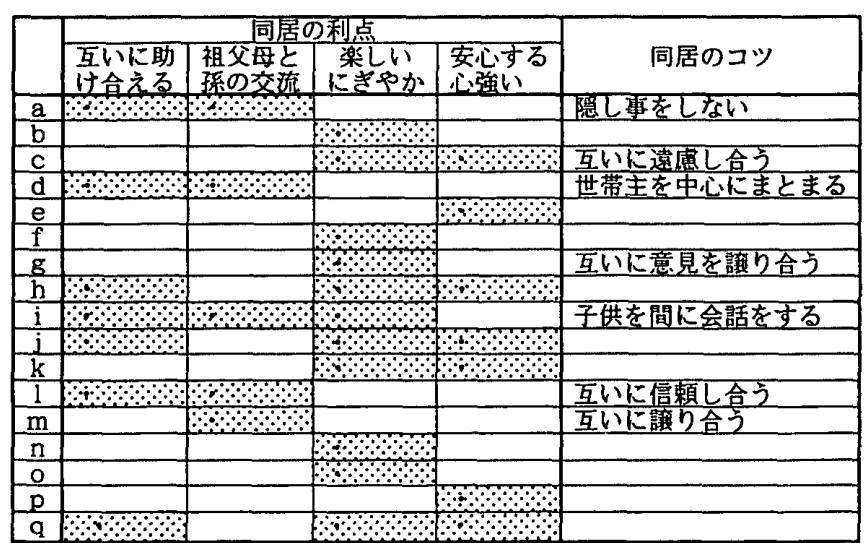

図16 同居への評価と住まい方のコツ

加え、「ムカエル」部屋の細分化や、子供部屋の充実な ど要素単位での生活の充実を要求している反面、同居の コッとしては「世帯主世代を中心としてまとまる」「互 いに遠慮しあう」「譲り合う」「信頼し合う」などの、 要素間あるいは世代間の心の譲り合いをあげいる。つま り、これからも、通世代家族の同居では、要素間の心の 交流や相互扶助を大切にしながら、通世代家族単位での 生活及び住空間と、要素単位あるいは夫婦単位での生活 や住空間を充実させることをふまえれば、通世代家族の 同居の可能性があるといえる（図16）。

7.まとめと今後の展開 現代でも共に住み繶けている 通世代家族では、要素は人格を尊重しながらも、互いに 役割を分担することで、家族の一員として位置づけられ、 安心した生活を営んでいる。また、現代の通世代家族は 同居を高く評価し、これからの通世代家族の同居の可能 性を示唆させる。

現代的な通世代家族の住まい方には、従来の同居慣習 の住まい方を規範としながら、「ックル」「タベル」 「ダンラン」「ムカエル」に生活単位の重層性をみせ、 生活単位の重層性に連動するかたちで、利用する部屋の 重層性が表出する、という特徵をみせる。

すなわち、現代の通世代家族の住空間計画では、(1) 「ネル」での生活単位の細分化と、生活単位別にもうけ られる部屋構成（私的住空間の構成）、(2)「ックル」 「タベル」「ダンラン」「ムカエル」での生活単位の重 層性と、連動する部屋の重層的な構成（共的住空間の構 成）、(3)通世代家族単位を崩さず永続的に行われる「才 コナウ」での部屋の位置づけ（公的住空間の構成）、が ポイントであり、それぞれの特性に応じた住空間の計画 が重要であると考える。

今後は、通世代家族の住空間のうち、私的住空間・共 的住空間・公的住空間それぞれに焦点をあて、それぞれ の住空間構成を詳細に検討し、現代的な通世代家族の住 空間を解明、これからの通世代家族の住空間計画指針を 明らかにしたい。

\section{謝辞}

末筆ながら、調査にご協力いただきました調査対象の 皆さまに心から感謝申し上げます。

\section{参考文献・注}

*1その土地で琵生と他界を程り返し、承税的に生活を営んでいる家旅を示 ఫ

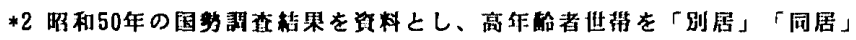
に分類、都道府県㓢に集胡・考察したものである。清水浩昭：「贯村老人の

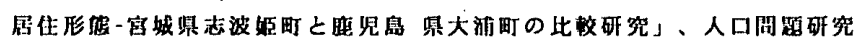

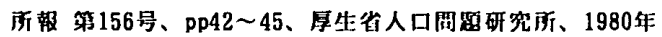

*3川本影：「近代社会における家の榑造小、社会思照社、1973年

*4落原国理子：「新・家旅の時代」、中公新落、1992年

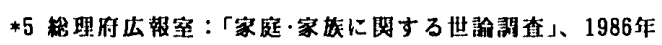

*6 二世带住宅研究所：「新二世带住宅百科小媢化成株式会社、1990年 他 *7 朝日新閩 1993 年4月24日服

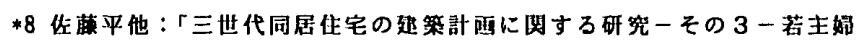

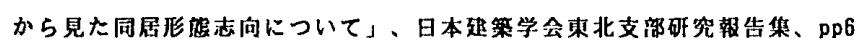
9 72、1985年、「三世代同居住宅の建策計西に园する餅究ーその4-用性

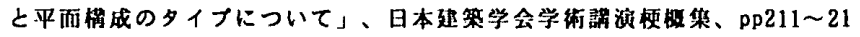

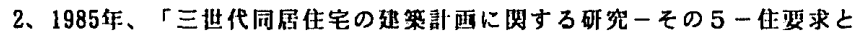

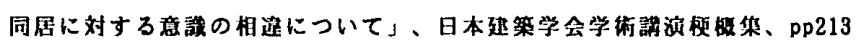
〜214、1985年、「三世代同居住宅の建築部西に関する阼究一その6-日常

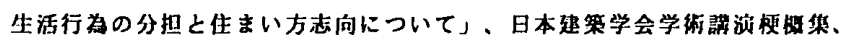

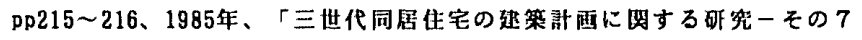
一分居形发世带に関するケース・スタティ」、日本建筑学会來北支部研究 報告集、pp87 90、1985年

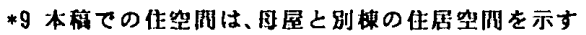

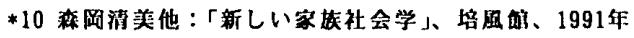

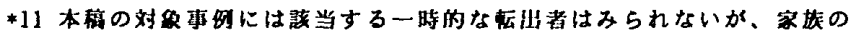

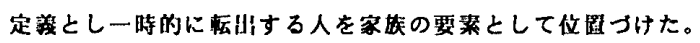

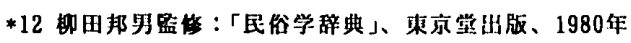

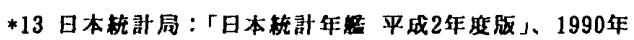

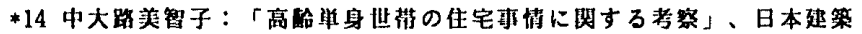
学会学街諳演极集、pp629 630、1987年

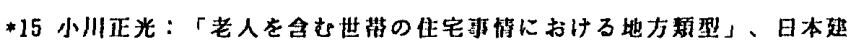

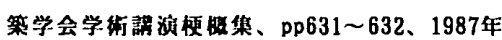

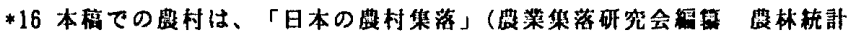

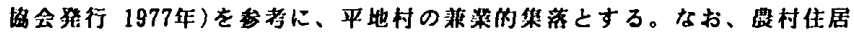

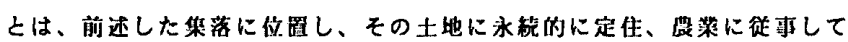
いる家族成貝がー人以上模らしている住居を示す

*17 林如子他：「住まい方から住驾間をデザインする」、影国社、1991年

（1995年 2 月 10 日原稿受理， 1995年 8 月16日採用決定） 